\title{
HIV evolution and diversity in ART-treated patients
}

\author{
Gert van Zyl ${ }^{1}$, Michael J. Bale ${ }^{2}$ and Mary F. Kearney ${ }^{2^{*}}$ (D)
}

\begin{abstract}
Characterizing HIV genetic diversity and evolution during antiretroviral therapy (ART) provides insights into the mechanisms that maintain the viral reservoir during ART. This review describes common methods used to obtain and analyze intra-patient HIV sequence data, the accumulation of diversity prior to ART and how it is affected by suppressive ART, the debate on viral replication and evolution in the presence of ART, HIV compartmentalization across various tissues, and mechanisms for the emergence of drug resistance. It also describes how CD4+ T cells that were likely infected with latent proviruses prior to initiating treatment can proliferate before and during ART, providing a renewable source of infected cells despite therapy. Some expanded cell clones carry intact and replication-competent proviruses with a small fraction of the clonal siblings being transcriptionally active and a source for residual viremia on ART. Such cells may also be the source for viral rebound after interrupting ART. The identical viral sequences observed for many years in both the plasma and infected cells of patients on long-term ART are likely due to the proliferation of infected cells both prior to and during treatment. Studies on HIV diversity may reveal targets that can be exploited in efforts to eradicate or control the infection without ART.
\end{abstract}

Keywords: HIV diversity, Antiretroviral therapy (ART), HIV genetics, HIV replication, HIV reservoir, HIV persistence, Expanded clones

\section{Background}

A signature of HIV infection is its vast genetic diversity and rapid evolution within and between infected individuals. HIV diversity results primarily from the lack of a proofreading mechanism by its reverse transcriptase (RT) enzyme that copies its RNA genome into DNA prior to integration into the host genome where it either remains latent or is expressed using the host cell machinery. HIV diversity is also influenced by a large population size and high recombination rate [1-4]. Other factors that contribute to the high genetic diversity of HIV are host APOBEC-mediated substitutions $[5,6]$ and changes in the population of susceptible cells over the duration of infection [7, 8] and across different anatomical compartments, such as the brain [9-11]. HIV evolution is

\footnotetext{
*Correspondence: kearneym@ncifcrf.gov; kearneym@mail.nih.gov

2 HIV Dynamic and Replication Program, Center for Cancer Research, National Cancer Institute at Frederick, 1050 Boyles Street, Building 535, Room 109, Frederick, MD 21702-1201, USA

Full list of author information is available at the end of the article
}

driven, in large part, by the selection of expressed variants that carry mutations allowing escape from cell killing or virus neutralization by host immune responses [12-15]. Immune escape is also one mechanism that allows the virus to persist within the host, with another mechanism being proliferation of latently-infected cells $[16,17]$. The latter mechanism is not affected by ART and is an important reservoir for the virus during suppressive treatment [18-20]. The interplay of all these factors explains why HIV sequences within an infected individual can differ by $5 \%$ or more $[12,21]$. The major implications of viral diversity are the persistence of HIV despite strong immune responses, the selection of drug resistant mutations on ART, and the difficulties it imposes on the development of vaccines and curative strategies. In this review article, we will discuss some methods used to measure and view HIV diversity, the accumulation of HIV diversity in untreated individuals, the influence that ART imposes on HIV diversity, the relationship between HIV diversity and the reservoir on ART, and how HIV diversity can lead to the emergence of drug resistant variants and virologic failure. 


\section{Methods to investigate HIV diversity in vivo Single-genome amplification and sequencing}

The methods by which we measure and analyze intrapatient viral populations are paramount to our understanding of HIV diversity and evolution. Early studies utilized bulk PCR amplification and cloning to measure HIV diversity and to detect the emergence of drug resistance mutations [22-25]. However, a letter by Liu et al. discussed the issues with this type of sequence analysis, especially in the context of low viral burden, showing that the resampling probability is inversely proportional to sample size-i.e. viral burden-and thus, bulk PCR and cloning can give erroneous estimates of intra-patient diversity [26]. This skewed quantitation of intra-patient sequence diversity resulted in detection of only the majority variants present in the HIV population [26-30].

In 2005, Palmer et al. [30] showed that the standard genotyping methods missed drug resistance mutations including mutations that were linked on the same viral genomes. In order to better understand intra-patient HIV populations, Palmer et al. developed an approach, based on similar approaches by Simmonds et al. [31], by utilizing limiting-dilution PCR to amplify from single HIV RNA or DNA templates [30]. Single-genome amplification or single-genome sequencing (SGA and SGS respectively) has been shown to have a low error rate of $0.003 \%$, and a very small assay recombination rate of less than one crossover event in 66,000 bp [30]. Salazar-Gonzales et al. later showed that, in a side-by-side comparison of bulk methods to SGS, that sequences derived by bulk methods had a noticeable error rate that contributed to a statistically significant difference between the two sets of paired sequences [13]. Jordan et al. further showed that neither bulk PCR/cloning nor SGS provided more bias than the other but noted that SGS could provide a deeper look at those sequences which would be missed by bulk PCR/ cloning methods [27].

\section{Next-generation sequencing}

Although SGS has become the gold-standard assay for studying HIV populations, it can only provide a limited look-without a herculean effort-at the intra-patient population. To address the issue of finding minority variants, and generating the maximum amount of data, various platforms of next-generation sequencing have been applied to HIV. High-throughput sequencing techniques have recently become popular and provide a deeper look at the HIV populations within patients and to search for variants that might be missed with lower throughput methods, such as rare drug resistance mutations. 454 pyrosequencing by Roche Diagnostics/454 Life Sciences has been the most prevalent deep sequencing method by which intra-host populations have been analyzed. It has been used to look at HIV populations with multiple alleles at single sites as well as searching for minority variants that may contribute to virological failure on ART [32-35]. However, in contrast to SGS, the requirement of a bulk PCR step in 454 and other deep sequencing methods can introduce artifactual recombination creating variants that are not present in the original population. PCR recombination rates have been reported to range from $5.4 \%$ recombinants to up to $37 \%$ recombinants $[28,36]$. To combat these recombination rates, which hinder the search for linked minority mutations in HIV populations, Boltz and Rausch et al. [36] developed an ultrasensitive SGS (uSGS) assay, performed on the Illumina Miseq platform, that reduces PCR recombination to about $0.1 \%$. uSGS works by incorporating primer-IDs onto cDNA molecules at the RT-PCR step [37] and then ligates adaptors which limits PCR bias and recombination by avoiding PCR with lengthy primers [36] used in other deep sequencing approaches. When applied to clinical samples, uSGS gave between 30 - and 80 -fold more sequences than standard SGS. However, in its current version, it is limited by the fragment length that can be analyzed, about 500 base pairs. Other advancements in deep sequencing approaches have allowed for the generation of whole- or near full-length genome sequences for rapid genotyping, SNP frequency calculations, and phylogenetic analyses [38-42]. In addition, more recent advances such as the Oxford Nanopore Technologies MinION and Pacific Biosciences SMRT sequencing are rapidly gaining traction as third generation technologies for HIV analyses [43].

\section{Analysis of intra-patient HIV sequence data}

Methods used to analyze HIV sequence data are equally important to those used to generate them. Average pairwise distance (APD) is the most common sequence-based statistic used in SGS studies as it can inform estimations of the within-host genetic diversity of the HIV populations. The traditional way to visualize the diversity of HIV populations is by phylogenetic trees. The most basic approach to phylogenetic analyses of intra-patient HIV sequence data are neighbor joining methods. Neighbor joining trees generate branch lengths solely from the absolute genetic distance between sequences and (generally) make no assumptions on either a temporal structure or rates between transitions or transversions. However, maximum-likelihood methods and Bayesian methods of phylogeny, which have also been applied to intra-patient HIV sequence sets [44-47], apply evolutionary models that account for frequencies of transitions and transversions and may consider the time of sample collection in generating the trees. Using the branch lengths on trees as surrogates for evolutionary change can provide 
insight into the relative levels of polymorphism between sequences and into changes in the population structure over time. Studies investigating compartmentalization or divergence over time utilize different hypothesis-testing methods, such as the test for panmixia [48, 49] or the Slatkin-Maddison test [50], to show the presence, or lack thereof, of different population structures either between anatomical compartments or at different timepoints. Analyses of intra-patient HIV sequence data have led to a better understanding of HIV transmission [12, 51], the accumulation of viral diversity prior to ART initiation [4, $12,52]$, the HIV population size [3, 4], the sources of persistent viremia on ART $[46,53,54]$, and the mechanisms that maintain the HIV reservoir on ART $[16,17]$.

\section{HIV genetic diversity and divergence in vivo Accumulation of diversity in early and chronic HIV infection}

HIV transmission is a relatively inefficient process with less than $1 \%$ of heterosexual exposures resulting in transmission and most associated with a single founder virus $[12,51]$. During sexual transmission, mucosal infection of the new host results in a bottleneck which selects for viruses with higher overall fitness [55]. However, in men who have sex with men (MSM) or intravenous drug users
(IVDU), when the exposure risk is high, selection for fit variants is less stringent. Moreover, the transmission of a first variant statistically increases the chance that another would transmit (transmissions do not follow a Poisson distribution). Thus, multiple founding viruses are not uncommon among MSM and IVDU, but their frequency varies across studies in accordance with the variable exposure risk [55-57]. Similar to heterosexual transmission, mother to child transmission is usually associated with one variant only, suggesting a stringent bottleneck [58]. Founding viruses are more likely CCR5 tropic, although, in some studies, up to $20 \%$ may be CXCR4 tropic $[51,59,60]$. As the initial infected target cells are activated $\mathrm{CD} 4+\mathrm{T}$ cells, founding viruses require a high CD4 receptor density and may be underglycosylated compared to strains from chronic infection [61].

When only one founding virus is transmitted, the viral population is initially homogenous (Fig. 1a) but diversifies as it adapts to a new host to levels of about $1-2.5 \%$ in the viral enzymes [12] and to $5 \%$ or more in the structural genes (Fig. 1b) [12, 13, 52]. This finding was more recently demonstrated in Zanini et al. [40, 42] through wholegenome analysis of untreated patients followed longitudinally. The authors showed that the HIV genome does not evolve uniformly, with the viral enzymes having a lower

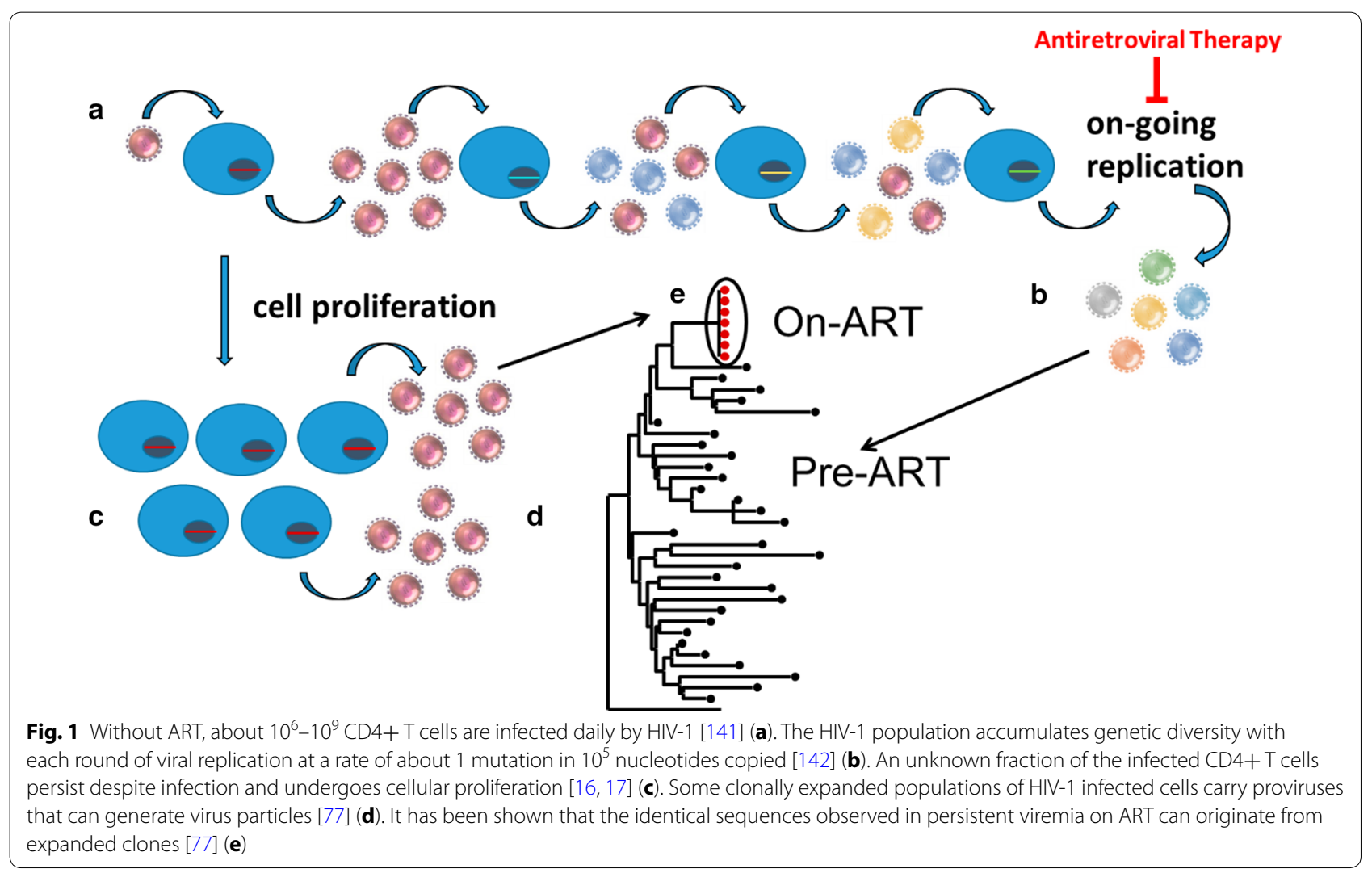


rate of divergence compared to gp120 and nef. In cases with multiple founding viruses, viral populations evolve through recombination in addition to mutation $[12,56$, 57, 62-64]. In non-controlling patients, HIV diversifies rapidly as variants that escape dominant cytotoxic $\mathrm{T}$ lymphocyte (CTL) responses are selected [12, 13, 40, 65]. However, when the HLA class I haplotype of the transmitting donor corresponds to the recipient, the transmitted variant may be a pre-adapted escape variant. Such transmission of escape variants as well as higher multiplicities of infection have been associated with a higher viral load and a more rapid disease progression in the new host [66]. In contrast, natural controllers are characterized by a greater magnitude, polyfunctionality, and breadth of CTL responses and the targeting of epitopes are conserved due to the high fitness cost of escape [67, 68]. Similar to CTL escape, escape from neutralizing antibodies through evolution of env, encoding the surface glycoprotein, occur as early as in the first months of infection [69]. In chronic untreated infection, viral evolution may favor the selection of strains that are less resistant to CTL killing but could infect a larger range of host cells, which may manifest as a switch from CCR 5 tropic strains to dual tropic or CXCR4 tropic strains [70]. This tropism switch is associated with more rapid disease progression [71]. In untreated individuals, adaptive responses to evolving B cell epitopes and sequential antibody escape, can result in the development of broadly neutralizing antibodies. Approximately $20 \%$ of chronically infected individuals develop broadly neutralizing antibodies, usually appearing late, as they are often produced by B-cells that have evolved extensively through somatic hypermutation and B cell selection [72, 73]. As mentioned above, although HIV diversifies rapidly in patients, patients in chronic infection experience a diversification plateau independent of continued viral turnover [4].

\section{HIV genetic diversity on ART}

The dynamics of plasma HIV RNA decay after initiating ART occurs in four phases and, oftentimes, results in an associated decline in the overall HIV genetic diversity [53, 74-76]. The first phase of decay occurs from the rapid death of most infected cells within days after initiating ART. The second phase is from the clearance of infected cells with half-lives of about $2-3$ weeks. The third is from longer-lived cells with half-lives of 6-44 months and the last phase has a slope that is not significantly different from zero, likely resulting from the persistence and/ or proliferation of infected cells that were previously latently-infected but, some fraction of which, produce virus upon stochastic activation [74-78]. A study by Besson et al. [79] investigated the decay of HIV DNA on ART and showed that the infected cell populations decline initially but then achieve a steady state with the persistence of about $10 \%$ of infected cells during longterm ART. The persistence of a small fraction of infected cells during ART may be achieved by maintaining a balance between cellular proliferation and cell death.

The diversity of HIV populations is influenced by the loss of the vast majority of infected cells on ART and the unveiling of identical proviruses that persist in proliferating populations of CD4+ T cells (Fig. 1c) $[46,53,54$, 80]. These monotypic sequences were first described by Bailey et al. [46] and were detected in the plasma, likely resulting from virion release from some members within clonally expanded populations (Fig. 1d, e). Maldarelli et al. [16] and Wagner et al. [17] were the first to directly show that HIV-infected cells can clonally expand and persist despite ART, and that the proviral integration site may influence this phenomenon. In one case, a provirus in an expanded cell clone was shown to match the single viral variant present at detectable levels in the persistent viremia during ART [77]. Furthermore, the virus particles produced by the clonally expanded cells were replication competent [77]. This one example is the only case, thus far, where the source of infectious virus in blood has been traced to a clone of infected cells carrying a mostly latent provirus. However, studies by Lorenzi et al. [20], Bui et al. [18], and Hosmane et al. [81] demonstrated that expanded cell clones harboring replication-competent proviruses are not uncommon among ART treated patients.

Characterizing the genetics of the HIV reservoir may help us to elucidate the mechanisms that established it prior to ART and that maintain it during ART. It is thought that the reservoir is comprised by a small number of resting, memory CD4+ $\mathrm{T}$ cells carrying transcriptionally silent HIV proviruses [82, 83]. Reports showing that the virus can reemerge months to years after treatment interruption in patients hoped to have been cured by bone marrow transplantation [84] or early treatment [85] support the idea that HIV can rebound from a pool of latently infected cells. However, more recent studies suggest that it may also consist of cells with transcriptionally active proviruses during ART that match those that rebound when ART is interrupted [86]. Although there is considerable patient-to-patient variation, the frequency of resting $\mathrm{CD} 4+\mathrm{T}$ cells that harbor HIV proviruses detectable by PCR has been very roughly estimated to average about 1 cell in $10^{3}$; however, the number of latently infected cells carrying replication-competent proviruses has been reported to be much lower [5, 87]. The difference is due to the presence of a large number of defective proviruses. Ho et al. [87] described the proviruses in resting $\mathrm{CD} 4+\mathrm{T}$ cells that were not induced to produce replication-competent virus after a single round 
of maximal $\mathrm{T}$ cell activation. Almost half of these proviruses had large internal deletions that preclude replication, while another third were lethally hypermutated by the host restriction factor APOBEC3G. Other defects and further analyses brought the fraction of defective proviruses up to $>98 \%$ [5]. Additionally, Ho et al. found that some of the intact proviruses were capable of producing infectious virions following a second round of activation [87], even though they had not been induced by the prior activation. Bui et al. [18] confirmed this finding and showed that sequential rounds of activation induced proliferation and expression from expanded cell clones.

Long-fragment PCR and sequencing revealed the proviral population structure in patients prior to ART and how the structure changes on long-term ART [5]. Early after infection, a large proportion of proviruses have ABOBEC-induced hypermutations and few have large internal deletions. However, as hypermutated proviruses produce and present aberrant peptides on HLA class I and are recognized by CTL, they are often eliminated whereas those with large internal deletions, and not producing antigen, may persist and continue to expand [88]. In contrast, reservoir cells harboring fully intact, replication-competent proviruses have been reported to be resistant to CTL killing, even though the viruses they release upon in vitro stimulation can be recognized by CTL [88]. This resistance to CTL killing may be due to a large fraction of the infected cells being transcriptionally silent in vivo and may explain the stability of this small pool of "true" reservoir cells [78].

\section{Controversy of ongoing HIV replication during ART}

Residual viremia per se is not evidence for ongoing replication. Current ART inhibits attachment and fusion, reverse transcription, integration, or particle maturation after release. However, it does not prevent virus production or release which requires the transcription of provirus, translation, virus assembly and exocytosis. Considering this, as long as infected cells persist and may become activated, viral release is possible, even in the absence of the infection of new cells. Although it has been shown that one mechanism that maintains the HIV reservoir is the persistence and proliferation of cells infected before the initiation of ART $[16,17,19,20,38$, $39,77]$, there is continued debate as to whether the reservoir can also be maintained from ongoing viral replication in potential ART sanctuary sites, such as lymph nodes (LN) [44, 89-92] with subsequent trafficking of recently infected cells into the blood [44, 93]. If ongoing replication in tissues maintains the HIV reservoir, then preventing infection of new cells by developing antiretrovirals that better penetrate sanctuary sites, such as $\mathrm{LN}$, would be a high priority. Conversely, if current ART is fully effective at blocking full cycles of viral replication in both tissues and blood, then elimination of proliferating and long-lived infected cells would be the highest priority to achieve an HIV-1 cure. It is therefore critical that the efficacy of current ART be fully understood to identify the most appropriate curative strategy.

Residual viremia due to ongoing viral replication, in patients without drug resistance, would require the presence of drug sanctuaries where the drug penetration is insufficient, allowing ongoing rounds of infection. Evidence of poor drug penetration in LN and mucosa associated lymphoid tissue (MALT) exist [90] and recently an investigation using 454 sequencing and a Bayesian evolution model on samples from LN tissue and blood of 3 patients reported evidence of evolution in LN with trafficking to the blood [44]. The authors concluded that the reservoir is replenished by ongoing replication and suggest the need for better ART with improved penetration into drug sanctuaries. These findings have, however, not been reproduced by other investigators or by applying different models of evolution on the same dataset [94]. If ongoing replication is important in replenishing the reservoir, viral diversification would continue in most patients on therapy and newly emergent variants would be detectable in the periphery as infected cells migrate between compartments. However, most studies of patients on long-term suppressive antiretroviral regimens have not found evidence of sequence diversification from pre-therapy in blood or tissues [41, 45, 46, 53, 54, 95]. Also, if low level viremia was due to ongoing HIV replication as a result of inadequate suppression of replication by triple combination therapy, the addition of a fourth drug, referred to as therapy intensification, would result in a decreased viral load. However, most investigations reported no viral load reduction with treatment intensification [96-99]. Taken together there exists no conclusive evidence that modern combination ART is inadequate and contributes to viral persistence in individuals with viral loads below the detection limit of commercial assays.

Most studies addressing the question of ongoing replication on ART analyzed HIV sequence data in longitudinal samples for evidence of evolution of virion RNA or proviral DNA in adults who initiated ART in chronic infection $[44,46,53,54,86,100]$, in adults who initiated ART in early infection $[53,54]$, and in perinatally-infected infants $[101,102]$. Performing SGS on individuals in early infection makes it easy to detect the mutations that accumulate with viral replication since the background genetic diversity is typically low. Using measures of diversity, divergence, and increasing branch lengths on phylogenetic trees over time, significant 
changes in HIV populations have not been reported in patients with sustained suppression of viremia on ART $[53,54,102,103]$ and suggest that the HIV reservoir is likely maintained largely, if not solely, by the persistence and expansion of cells that were infected prior to the initiation of treatment. However, most studies looking for evidence of HIV evolution on ART due to viral replication have been conducted on blood samples. Fewer studies have been performed on tissues collected from various anatomical sites. Results of studies on HIV evolution during ART in tissues, including those using nonhuman primate models, have been conflicting with some showing evidence of viral compartmentalization and evolution [44] while others claim the opposite conclusion [104]. The conflicting outcomes may result from differences in the methods used to perform the sequencing (deep sequencing vs. SGS), from the methods used to analyze the data (neighbor joining vs. Bayesian phylogenetics), whether the identical variants are collapsed to a single sequence or not [105], or simply from sampling error. It is obvious that more studies are needed to determine if ongoing cycles of HIV replication occur in any tissues during ART to levels that could sustain the reservoir and lead to viral rebound when ART is interrupted.

\section{HIV compartmentalization}

Viral compartmentalization describes tissues or cell types where viral replication occurred but anatomical barriers restrict both ingoing and outgoing viral gene flow [106]. As discussed earlier, one theory is that the viral reservoir is maintained by ongoing HIV replication in sanctuary sites where drug penetration is sub-optimal [90]. In addition to the $\mathrm{LN}$, the gut lymphoid tissue has also been posited as another such site of compartmentalization. A study by van Marle et al. [107] analyzed samples from the esophagus, stomach, duodenum, and colorectum and found evidence of compartmentalization in the nef region of the HIV genome. Furthermore, a study by Yukl et al. [108] showed that the overall burden of HIV within the gut is much higher than in the blood which may suggest that ongoing replication during ART persists within this compartment. Along these lines, a later study by Rueda et al. [109] showed increased and prolonged activation of the immune system within the gut, suggesting that immune cells were being exposed to viral protein. In contrast, Imamichi et al. showed a lack of compartmentalization between the proviral sequences derived from PBMC and from the ileum and colon [110]. This result was later corroborated by Evering et al. [45] who showed no difference in proviral sequences from the blood or gut mucosa. Evering further demonstrated that there was no evidence of ongoing rounds of viral replication due to a lack of detectable accumulation of diversity within the sequence data despite higher levels of immune activation within the gut [45]. This latter result was confirmed by Josefsson et al. [54] and, later, Simonetti et al. [77] who found minimal genetic changes over time and no evidence for compartmentalization between the periphery and the gut after long-term therapy.

Although there is some debate regarding the compartmentalization of HIV in lymphoid tissue, the central nervous system (CNS) is one such compartment in which heavy restriction of gene flow affects the population structure $[9-11,111]$. The compartmentalization of the CNS has been found to be strongly associated with HIV-Associated Dementia (HAD) [112, 113]. Studies by Schnell et al. $[9,10]$ and later, Sturdevant et al. [11] found two distinct types of compartmentalization within the cerebrospinal fluid (CSF). The authors reported that the $\mathrm{T}$ cell tropic virus found in the CSF was generally clonal in nature, and associated with pleocytosis, whereas macrophage-tropic virus (CD4+ low) was generally diverse and contained variants not represented in the plasma $[9,10]$. These results suggested that HIV could replicate in at least two cell types within the CNS, but the authors noted that there was no relationship between the tropism of the virus and HAD diagnosis [11]. A recent study by Stefic et al. [111] attempted to enumerate differential selective pressures between the blood and CNS in the context of neutralizing antibodies. The authors reported that variants in the CNS had no differential ability to escape autologous neutralization when compared to the blood, but that there was a general increase in resistance to broadly neutralizing antibodies that was independent of compartmentalization, suggesting that the CNS could have clinical implications for immunotherapies [111].

Multiple studies have shown that the genital and genitourinary tracts are another site of compartmentalization within an HIV-infected patient [114-116]. However, in contrast to these studies, Bull and colleagues published two studies showing that female genital tract sequences are typically monotypic in nature, most likely due to cellular clonal expansion of single variants [105, 117]. Bull and colleagues later showed that these monotypic populations do not form distinct lineages over time and are well mixed with the blood [118]. In addition, a study by Chaillon et al. [119] found evidence of compartmentalization between semen and blood, but that this structure did not persist over the timepoints analyzed. Taken together, these studies show that there is a complex interplay between the plasma and various anatomical sites throughout the body and that eradication strategies may require monitoring of both the blood and these anatomical sites. 


\section{Production of virus from clonally-expanded populations of infected cells}

When HIV infected cells proliferate, proviral sequences are replicated with the high-fidelity cellular DNA polymerase, resulting in identical copies of the original provirus. Evidence for clonal proliferation as the source of persistent viremia, rather than ongoing cycles of viral replication, was first provided by finding the persistence of a large proportion of identical plasma sequences during residual viremia [46, 53]. This suggested that the identical viruses found in plasma may be produced by cells that have undergone clonal proliferation. The large majority of virus producing clones have defective proviruses, as intact gag alone is required for non-infectious particles to assemble [120]. Defective proviruses are the likely major contributor to persisting low level viremia. This explains the large proportion of identical sequences in residual viremia and the lack of linkage of persisting low level viremia with replication competent virus or virus rebounding after therapy interruption $[46,100]$. Recently, novel assays to investigate HIV integration sites have been developed, which revealed that proviral integration in or near growth genes is associated with selective survival and expansion of infected CD4+ T cell clones $[16,17]$. As described previously, it has also been shown that CD4 clones could harbor intact and replication-competent proviruses $[18,20,77,81]$ and that these clones contain members that are transcriptionally active $[77,78]$ and can be the source of persistent viremia [77] and of viral rebound [86]. In addition, recent studies have focused on the different $\mathrm{T}$ cell subsets with respect to locating clones with intact proviruses. Lee and colleagues found that identical variants were preferentially in Th1-polarized cells [38] and Hiener et al. [39] found intact proviruses in effector memory $\mathrm{T}$ cells. Taken together, these studies emphasize the role of cellular proliferation in maintaining of the HIV reservoir and suggest that further studies are needed to determine the association between different cell subsets and the clonal expansion of infected cells. It has been further suggested that there is an inverse relationship between the size of proviral clones and their probability of harboring replication-competent virus [20]. This may be explained by CD4 clones with large internal proviral deletions being less susceptible to CTL killing [88]. Taken together this explains why residual viremia in patients on long term ART may predominantly originate from defective proviruses and why there is an absence of correlation of residual viremia and quantitative infectious virus recovery [121].

\section{Emergence of drug resistance}

Although ART is highly effective at inhibiting viral replication, drug resistant variants can emerge if ART is taken intermittently or if resistance mutations were present in the population prior to its initiation. HIV drug resistance was first observed with zidovudine/azidothymidine (AZT) monotherapy with the selection of thymidineassociated mutations (TAMs) in the reverse transcriptase gene that were likely present at low levels prior to AZT exposure [122]. In contrast, triple combination ART, which first included either a protease inhibitor (PI) and two nucleos(t)ide reverse transcriptase inhibitors (NRTIs) or a non-nucleoside reverse transcriptase inhibitor with two NRTIs, resulted in sustained viral suppression in the majority of patients and a low prevalence of drug resistance in patients with high levels of adherence [123-125].

The remarkable success of combination ART has two main explanations. First, variants carrying multiple drug resistance mutations are unlikely to be present in the viral population prior to ART and, therefore, cannot be selected when adherence is sufficiently high enough to virtually block further ongoing cycles of viral replication. The much lower frequency of virologic failure due to drug resistance on combination ART is consistent with studies showing a lack of viral replication and evolution on therapy. Secondly, when combination therapy includes drugs with a high genetic barrier (requiring multiple mutations for resistance), such as the newer integrase strand transfer inhibitors (INSTIs), or when mutations have a high fitness cost, the probability of their existence and selection is even lower [126]. In particular, resistance to the new INSTI, dolutegravir (DTG), when used in combination ART appears to be exceedingly rare. This phenomena can be explained by its high genetic barrier and the high fitness cost of the drug resistant variants [127]. Consequently, dual treatment combinations of DTG with lamivudine or rilpivirine are currently being investigated in clinical trials $[128,129]$. Nevertheless, when patients who are INSTI-experienced, have inadequate adherence or received DTG monotherapy, resistance has occurred [130-132]. Thus, even regimens with high genetic barriers could be compromised by pre-existing resistance, inadequate regimen formulations and insufficient adherence. In addition to high genetic barrier, the potency of particular drugs has been related to their ability to prevent new rounds of infection in single-cycle replication assays, referred to as the instantaneous inhibitory potential (IIP). Drugs with a high IIP may contribute to highly durable regimens by virtually halting viral replication and thereby preventing viral evolution [133, 134]. Taken together, high potency and high genetic barrier regimens 
have contributed to the prevention of antiviral escape and the success of combination ART to prevent disease progression.

Considering the effectiveness of modern ART, it begs the question why virologic failure due to drug resistance still occurs. A major predictor of regimen failure is significant pre-existing drug resistance resulting from previous drug exposure $[35,135,136]$, transmitted drug resistance [137], or possibly, high viral population size $[3,138]$. However, even without pre-existing resistance, inadequate adherence could create a favorable environment for the stochastic emergence and subsequent selection of resistant mutants. As the different components of combination regimens have different half-lives, breaks in therapy could effectively result in monotherapy of the component with the longest half-life, leading to the selection of drug resistance mutations. In particular, breaks in therapy containing NNRTIs that have long half-lives, are associated with a high risk of failure $[139,140]$.

\section{Conclusions}

Studies on intra-patient HIV genetic diversity on ART have contributed to our understanding of the establishment and maintenance of the reservoir that results in viral rebound when ART is interrupted $[16,17,46,53,77$, 86]. To date, scientific consensus has established that HIV replication is virtually halted in the peripheral blood of individuals fully suppressed on ART as most studies conclude that the viral population in PBMC does not diverge due to viral replication from pre-therapy populations for up to about 20 years on potent and adherent therapy $[40,53,54,102,103]$. However, whether viral replication persists in tissues, such as lymph nodes and gut, to levels that can maintain the HIV reservoir is still controversial $[44,45,90,104,107,110]$. Because newly infected cells are not detected in the peripheral blood even after many years on ART, if viral replication persists in tissues, it indicates that these cells rarely migrate outside of their anatomical site of infection. Studies on proviral compartmentalization aim to investigate viral gene flow to better understand the migration patterns of infected cells and address the question of ongoing HIV replication during ART in tissues. However, such studies, thus far, have come to contradicting conclusions with some showing evidence of compartmentalization between blood and lymphoid tissues [44, 107] and others showing a lack of compartmentalization $[45,54,110]$. The conflicting findings may be due to differences in methods used to obtain the sequence data and analyze them or in differences in the region or length of the gene fragments investigated. More in depth studies on HIV populations in multiple genes are needed to resolve this controversy and to determine if ongoing cycles of viral replication contribute to maintaining the HIV reservoir on ART.

It is now well established that a small fraction of the cells that were likely infected prior to starting ART or during treatment interruptions can persist on long-term ART through cellular proliferation. It is likely through silencing of viral gene transcription (latent infection) that these cells survive and divide despite infection. Furthermore, the proliferation of infected cells is, in some instances, is driven by the interruption of the cell cycle by integration of HIV proviruses into oncogenes or genes that regulate cell growth $[16,17]$. In one case, it was demonstrated that a large HIV infected cell clone was the source of persistent viremia and carried an archived, intact provirus that was capable of producing infectious virus in in vitro experiments [77]. This study was followed by others demonstrating that clones of cells carrying intact and replication-competent proviruses is not uncommon in individuals on suppressive ART [18, $20,81]$. These studies clearly show that a common reservoir for HIV infection during ART is the persistence and proliferation of cells infected with intact proviruses. More studies are needed to determine if such variants are always archival or if they can emerge from new rounds of infection in tissues during ART and to understand the distribution of cell clones across different anatomical compartments. Furthermore, single-cell studies are needed to confirm if the mechanism that allows the persistence of such clones is, indeed, HIV latency. Understanding the mechanisms that maintain the HIV reservoir will guide the design of strategies to eradicate the infection, such as the further development of agents aimed at driving infected cells out of latency, without inducing further cellular proliferation, so that HIV proteins can be targeted by, perhaps, a boosted immune system. Future studies on HIV diversity and evolution will likely guide this process and may contribute to evaluating the efficacy of curative interventions for HIV infection.

\section{Abbreviations}

ART: antiretroviral therapy; PBMC: peripheral blood mononuclear cells; LN: lymph node(s); APOBEC: apolipoprotein B mRNA editing enzyme, catalytic polypeptide-like; CNS: central nervous system; CSF: cerebral spinal fluid; IIP: instantaneous inhibitory potential; 454: 454 pyrosequencing.

\section{Authors' contributions}

GVZ, MJB, MFK wrote the article. All authors read and approved the final manuscript.

\footnotetext{
Author details

${ }^{1}$ Division of Medical Virology, Stellenbosch University and NHLS Tygerberg, Cape Town, South Africa. ${ }^{2}$ HIV Dynamic and Replication Program, Center for Cancer Research, National Cancer Institute at Frederick, 1050 Boyles Street, Building 535, Room 109, Frederick, MD 21702-1201, USA.
} 


\section{Acknowledgements}

We thank John Coffin and John Mellors for helpful advice and Connie Kinna for administrative support.

\section{Competing interests}

The authors declare that they have no competing interests.

\section{Ethical approval and consent to participate}

Not applicable.

\section{Funding}

Funding was provided by National Cancer Institute (Intramural) and National Institutes of Health (Grant No. 1U01Al116138-01).

\section{Publisher's Note}

Springer Nature remains neutral with regard to jurisdictional claims in published maps and institutional affiliations.

Received: 6 October 2017 Accepted: 18 January 2018

Published online: 30 January 2018

\section{References}

1. Hu WS, Hughes SH. HIV-1 reverse transcription. Cold Spring Harb Perspect Med. 2012;2:a006882.

2. Coffin J, Swanstrom R. HIV pathogenesis: dynamics and genetics of viral populations and infected cells. Cold Spring Harb Perspect Med. 2013;3:a012526.

3. Boltz VF, Ambrose Z, Kearney MF, Shao W, Kewalramani VN, Maldarelli F, Mellors JW, Coffin JM. Ultrasensitive allele-specific PCR reveals rare preexisting drug-resistant variants and a large replicating virus population in macaques infected with a simian immunodeficiency virus containing human immunodeficiency virus reverse transcriptase. J Virol. 2012:86:12525-30

4. Maldarelli F, Kearney M, Palmer S, Stephens R, Mican J, Polis MA, Davey RT, Kovacs J, Shao W, Rock-Kress D, et al. HIV populations are large and accumulate high genetic diversity in a nonlinear fashion. J Virol. 2013;87:10313-23.

5. Bruner KM, Murray AJ, Pollack RA, Soliman MG, Laskey SB, Capoferri AA, Lai J, Strain MC, Lada SM, Hoh R, et al. Defective proviruses rapidly accumulate during acute HIV-1 infection. Nat Med. 2016;22:1043-9.

6. Yu Q, Konig R, Pillai S, Chiles K, Kearney M, Palmer S, Richman D, Coffin $J M$, Landau NR. Single-strand specificity of APOBEC3G accounts for minus-strand deamination of the HIV genome. Nat Struct Mol Biol. 2004; $11: 435-42$

7. Zhou S, Bednar MM, Sturdevant CB, Hauser BM, Swanstrom R. Deep Sequencing of the HIV-1 env gene reveals discrete $X 4$ lineages and linkage disequilibrium between X4 and R5 viruses in the V1/V2 and V3 variable regions. J Virol. 2016;90:7142-58.

8. Arrildt KT, LaBranche CC, Joseph SB, Dukhovlinova EN, Graham WD, Ping LH, Schnell G, Sturdevant CB, Kincer LP, Mallewa M, et al. Phenotypic correlates of HIV-1 macrophage tropism. J Virol. 2015:89:11294-311.

9. Schnell G, Joseph S, Spudich S, Price RW, Swanstrom R. HIV-1 replication in the central nervous system occurs in two distinct cell types. PLoS Pathog. 2011;7:e1002286.

10. Schnell G, Price RW, Swanstrom R, Spudich S. Compartmentalization and clonal amplification of HIV-1 variants in the cerebrospinal fluid during primary infection. J Virol. 2010;84:2395-407.

11. Sturdevant CB, Joseph SB, Schnell G, Price RW, Swanstrom R, Spudich S. Compartmentalized replication of R5 T cell-tropic HIV-1 in the central nervous system early in the course of infection. PLoS Pathog. 2015;11:e1004720

12. Kearney M, Maldarelli F, Shao W, Margolick JB, Daar ES, Mellors JW, Rao V Coffin JM, Palmer S. Human immunodeficiency virus type 1 population genetics and adaptation in newly infected individuals. J Virol. 2009;83:2715-27.
13. Salazar-Gonzalez JF, Bailes E, Pham KT, Salazar MG, Guffey MB, Keele BF, Derdeyn CA, Farmer P, Hunter E, Allen S, et al. Deciphering human immunodeficiency virus type 1 transmission and early envelope diversification by single-genome amplification and sequencing. J Virol. 2008:82:3952-70.

14. Phillips RE, Rowland-Jones S, Nixon DF, Gotch FM, Edwards JP, Ogunlesi AO, Elvin JG, Rothbard JA, Bangham CR, Rizza CR, et al. Human immunodeficiency virus genetic variation that can escape cytotoxic $T$ cell recognition. Nature. 1991;354:453-9.

15. Wei X, Decker JM, Wang S, Hui H, Kappes JC, Wu X, Salazar-Gonzalez JF, Salazar MG, Kilby JM, Saag MS, et al. Antibody neutralization and escape by HIV-1. Nature. 2003;422:307-12

16. Maldarelli F, Wu X, Su L, Simonetti FR, Shao W, Hill S, Spindler J, Ferris AL, Mellors JW, Kearney MF, et al. HIV latency. Specific HIV integration sites are linked to clonal expansion and persistence of infected cells. Science. 2014:345:179-83.

17. Wagner TA, McLaughlin S, Garg K, Cheung CY, Larsen BB, Styrchak S, Huang HC, Edlefsen PT, Mullins JI, Frenkel LM. HIV latency. Proliferation of cells with HIV integrated into cancer genes contributes to persistent infection. Science. 2014;345:570-3.

18. Bui JK, Halvas EK, Fyne E, Sobolewski MD, Koontz D, Shao W, Luke B, Hong FF, Kearney MF, Mellors JW. Ex vivo activation of CD4+ T-cells from donors on suppressive ART can lead to sustained production of infectious HIV-1 from a subset of infected cells. PLoS Pathog. 2017;13:e1006230.

19. Bui JK, Sobolewski MD, Keele BF, Spindler J, Musick A, Wiegand A, Luke BT, Shao W, Hughes SH, Coffin JM, et al. Proviruses with identical sequences comprise a large fraction of the replication-competent HIV reservoir. PLoS Pathog. 2017;13:e1006283.

20. Lorenzi JC, Cohen YZ, Cohn LB, Kreider EF, Barton JP, Learn GH, Oliveira T, Lavine CL, Horwitz JA, Settler A, et al. Paired quantitative and qualitative assessment of the replication-competent HIV-1 reservoir and comparison with integrated proviral DNA. Proc Natl Acad Sci USA. 2016;113:E7908-16

21. Korber B, Gaschen B, Yusim K, Thakallapally R, Kesmir C, Detours V. Evolutionary and immunological implications of contemporary HIV-1 variation. Br Med Bull. 2001;58:19-42.

22. Simmonds P, Zhang LQ, McOmish F, Balfe P, Ludlam CA, Brown AJ. Discontinuous sequence change of human immunodeficiency virus (HIV) type 1 env sequences in plasma viral and lymphocyte-associated proviral populations in vivo: implications for models of HIV pathogenesis. J Virol. 1991;65:6266-76.

23. Meyerhans A, Cheynier R, Albert J, Seth M, Kwok S, Sninsky J, MorfeldtManson L, Asjo B, Wain-Hobson S. Temporal fluctuations in HIV quasispecies in vivo are not reflected by sequential HIV isolations. Cell. 1989:58:901-10.

24. St Clair MH, Martin JL, Tudor-Williams G, Bach MC, Vavro CL, King DM, Kellam P, Kemp SD, Larder BA. Resistance to ddl and sensitivity to AZT induced by a mutation in HIV-1 reverse transcriptase. Science. 1991;253:1557-9.

25. Leitner T, Halapi E, Scarlatti G, Rossi P, Albert J, Fenyo EM, Uhlen M. Analysis of heterogeneous viral populations by direct DNA sequencing Biotechniques. 1993:15:120-7.

26. Liu SL, Rodrigo AG, Shankarappa R, Learn GH, Hsu L, Davidov O, Zhao LP Mullins JI. HIV quasispecies and resampling. Science. 1996:273:415-6.

27. Jordan MR, Kearney M, Palmer S, Shao W, Maldarelli F, Coakley EP, Chappey C, Wanke C, Coffin JM. Comparison of standard PCR/Cloning to single genome sequencing for analysis of HIV-1 populations. J Virol Methods. 2010;168:114-20.

28. Shao W, Boltz VF, Spindler JE, Kearney MF, Maldarelli F, Mellors JW, Stewart C, Volfovsky N, Levitsky A, Stephens RM, Coffin JM. Analysis of 454 sequencing error rate, error sources, and artifact recombination for detection of Low-frequency drug resistance mutations in HIV-1 DNA. Retrovirology. 2013;10:18.

29. Kearney M, Palmer S, Maldarelli F, Shao W, Polis MA, Mican J, Rock-Kress D, Margolick JB, Coffin JM, Mellors JW. Frequent polymorphism at drug resistance sites in HIV-1 protease and reverse transcriptase. AIDS 2008;22:497-501.

30. Palmer S, Kearney M, Maldarelli F, Halvas EK, Bixby CJ, Bazmi H, Rock D, Falloon J, Davey RT Jr, Dewar RL, et al. Multiple, linked human immunodeficiency virus type 1 drug resistance mutations in 
treatment-experienced patients are missed by standard genotype analysis. J Clin Microbiol. 2005;43:406-13.

31. Simmonds P, Balfe P, Ludlam CA, Bishop JO, Brown AJ. Analysis of sequence diversity in hypervariable regions of the external glycoprotein of human immunodeficiency virus type 1. J Virol. 1990;64:5840-50.

32. Bushman FD, Hoffmann C, Ronen K, Malani N, Minkah N, Rose HM, Tebas P, Wang GP. Massively parallel pyrosequencing in HIV research. AIDS. 2008;22:1411-5.

33. Rozera G, Abbate I, Bruselles A, Vlassi C, D'Offizi G, Narciso P, Chillemi G, Prosperi M, Ippolito G, Capobianchi MR. Massively parallel pyrosequencing highlights minority variants in the HIV-1 env quasispecies deriving from lymphomonocyte sub-populations. Retrovirology. 2009;6:15.

34. Eriksson N, Pachter L, Mitsuya Y, Rhee SY, Wang C, Gharizadeh B, Ronaghi M, Shafer RW, Beerenwinkel N. Viral population estimation using pyrosequencing. PLoS Comput Biol. 2008;4:e1000074.

35. Boltz VF, Zheng Y, Lockman S, Hong F, Halvas EK, McIntyre J, Currier JS, Chibowa MC, Kanyama C, Nair A, et al. Role of low-frequency HIV-1 variants in failure of nevirapine-containing antiviral therapy in women previously exposed to single-dose nevirapine. Proc Natl Acad Sci USA. 2011;108:9202-7.

36. Boltz VF, Rausch J, Shao W, Hattori J, Luke B, Maldarelli F, Mellors JW, Kearney MF, Coffin JM. Ultrasensitive single-genome sequencing: accurate, targeted, next generation sequencing of HIV-1 RNA. Retrovirology. 2016;13:87.

37. Jabara CB, Jones CD, Roach J, Anderson JA, Swanstrom R. Accurate sampling and deep sequencing of the HIV-1 protease gene using a Primer ID. Proc Natl Acad Sci USA. 2011;108:20166-71.

38. Lee GQ, Orlova-Fink N, Einkauf K, Chowdhury FZ, Sun X, Harrington S, Kuo HH, Hua S, Chen HR, Ouyang Z, et al. Clonal expansion of genomeintact HIV-1 in functionally polarized Th1 CD4+ T cells. J Clin Invest. 2017;127:2689-96.

39. Hiener B, Horsburgh BA, Eden JS, Barton K, Schlub TE, Lee E, von Stockenstrom S, Odevall L, Milush JM, Liegler T, et al. Identification of genetically intact HIV-1 proviruses in specific CD4(+) T cells from effectively treated participants. Cell Rep. 2017;21:813-22.

40. Zanini F, Brodin J, Thebo L, Lanz C, Bratt G, Albert J, Neher RA. Population genomics of intrapatient HIV-1 evolution. Elife. 2015;4:e11282.

41. Brodin J, Zanini F, Thebo L, Lanz C, Bratt G, Neher RA, Albert J. Establishment and stability of the latent HIV-1 DNA reservoir. Elife. 2016:5:e18889.

42. Zanini F, Brodin J, Albert J, Neher RA. Error rates, PCR recombination, and sampling depth in HIV-1 whole genome deep sequencing. Virus Res. 2017:239:106-14.

43. Dilernia DA, Chien JT, Monaco DC, Brown MP, Ende Z, Deymier MJ, Yue L, Paxinos EE, Allen S, Tirado-Ramos A, Hunter E. Multiplexed highly-accurate DNA sequencing of closely-related HIV-1 variants using continuous long reads from single molecule, real-time sequencing. Nucleic Acids Res. 2015;43:e129.

44. Lorenzo-Redondo R, Fryer HR, Bedford T, Kim EY, Archer J, Pond SLK, Chung YS, Penugonda S, Chipman J, Fletcher CV, et al. Persistent HIV-1 replication maintains the tissue reservoir during therapy. Nature. 2016;530:51-6.

45. Evering TH, Mehandru S, Racz P, Tenner-Racz K, Poles MA, Figueroa A, Mohri H. Markowitz M. Absence of HIV-1 evolution in the gut-associated lymphoid tissue from patients on combination antiviral therapy initiated during primary infection. PLoS Pathog. 2012;8:e1002506.

46. Bailey JR, Sedaghat AR, Kieffer T, Brennan T, Lee PK, Wind-Rotolo M, Haggerty CM, Kamireddi AR, Liu Y, Lee J, et al. Residual human immunodeficiency virus type 1 viremia in some patients on antiretroviral therapy is dominated by a small number of invariant clones rarely found in circulating CD4+ T cells. J Virol. 2006;80:6441-57.

47. Kieffer TL, Finucane MM, Nettles RE, Quinn TC, Broman KW, Ray SC, Persaud D, Siliciano RF. Genotypic analysis of HIV-1 drug resistance at the limit of detection: virus production without evolution in treated adults with undetectable HIV loads. J Infect Dis. 2004:189:1452-65.

48. Hudson RR, Boos DD, Kaplan NL. A statistical test for detecting geographic subdivision. Mol Biol Evol. 1992;9:138-51.

49. Achaz G, Palmer S, Kearney M, Maldarelli F, Mellors JW, Coffin JM, Wakeley J. A robust measure of HIV-1 population turnover within chronically infected individuals. Mol Biol Evol. 2004;21:1902-12.
50. Slatkin M, Maddison WP. A cladistic measure of gene flow inferred from the phylogenies of alleles. Genetics. 1989;123:603-13.

51. Keele BF, Giorgi EE, Salazar-Gonzalez JF, Decker JM, Pham KT, Salazar MG, Sun C, Grayson T, Wang S, Li H, et al. Identification and characterization of transmitted and early founder virus envelopes in primary HIV-1 infection. Proc Natl Acad Sci USA. 2008;105:7552-7.

52. Shankarappa R, Gupta P, Learn GH Jr, Rodrigo AG, Rinaldo CR Jr, Gorry MC, Mullins JI, Nara PL, Ehrlich GD. Evolution of human immunodeficiency virus type 1 envelope sequences in infected individuals with differing disease progression profiles. Virology. 1998;241:251-9.

53. Kearney MF, Spindler J, Shao W, Yu S, Anderson EM, O'Shea A, Rehm C, Poethke C, Kovacs N, Mellors JW, et al. Lack of detectable HIV-1 molecular evolution during suppressive antiretroviral therapy. PLoS Pathog. 2014;10:e1004010.

54. Josefsson L, von Stockenstrom S, Faria NR, Sinclair E, Bacchetti P, Killian M, Epling L, Tan A, Ho T, Lemey P, et al. The HIV-1 reservoir in eight patients on long-term suppressive antiretroviral therapy is stable with few genetic changes over time. Proc Natl Acad Sci USA. 2013;110:E4987-96.

55. Carlson JM, Schaefer M, Monaco DC, Batorsky R, Claiborne DT, Prince J, Deymier MJ, Ende ZS, Klatt NR, DeZiel CE, et al. Selection bias at the heterosexual HIV-1 transmission bottleneck. Science. 2014;345:1254031.

56. Bar KJ, Li H, Chamberland A, Tremblay C, Routy JP, Grayson T, Sun C, Wang S, Learn GH, Morgan CJ, et al. Wide variation in the multiplicity of HIV-1 infection among injection drug users. J Virol. 2010;84:6241-7.

57. Li H, Bar KJ, Wang S, Decker JM, Chen Y, Sun C, Salazar-Gonzalez JF, Salazar MG, Learn GH, Morgan CJ, et al. High multiplicity infection by HIV-1 in men who have sex with men. PLoS Pathog. 2010;6:e1000890.

58. Russell ES, Kwiek JJ, Keys J, Barton K, Mwapasa V, Montefiori DC, Meshnick SR, Swanstrom R. The genetic bottleneck in vertical transmission of subtype C HIV-1 is not driven by selection of especially neutralization-resistant virus from the maternal viral population. J Virol. 2011:85:8253-62.

59. Sheppard HW, Celum C, Michael NL, O'Brien S, Dean M, Carrington M, Dondero D, Buchbinder SP. HIV-1 infection in individuals with the CCR5Delta32/Delta32 genotype: acquisition of syncytium-inducing virus at seroconversion. J Acquir Immune Defic Syndr. 1999;2002(29):307-13.

60. Chalmet K, Dauwe K, Foquet L, Baatz F, Seguin-Devaux C, Van Der Gucht $B$, Vogelaers D, Vandekerckhove L, Plum J, Verhofstede C. Presence of CXCR4-using HIV-1 in patients with recently diagnosed infection: correlates and evidence for transmission. J Infect Dis. 2012;205:174-84.

61. Ping LH, Joseph SB, Anderson JA, Abrahams MR, Salazar-Gonzalez JF, Kincer LP, Treurnicht FK, Arney L, Ojeda S, Zhang M, et al. Comparison of viral Env proteins from acute and chronic infections with subtype C human immunodeficiency virus type 1 identifies differences in glycosylation and CCR5 utilization and suggests a new strategy for immunogen design. J Virol. 2013;87:7218-33.

62. Abrahams M-R, Anderson JA, Giorgi EE, Seoighe C, Mlisana K, Ping L-H, Athreya GS, Treurnicht FK, Keele BF, Wood N, et al. Quantitating the multiplicity of infection with human immunodeficiency virus type 1 subtype $C$ reveals a non-poisson distribution of transmitted variants. $J$ Virol. 2009;83:3556-67.

63. Novitsky V, Wang R, Margolin L, Baca J, Rossenkhan R, Moyo S, van Widenfelt E, Essex M. Transmission of single and multiple viral variants in primary HIV-1 subtype C infection. PLoS ONE. 2011;6:e16714.

64. Batorsky R, Kearney MF, Palmer SE, Maldarelli F, Rouzine IM, Coffin JM. Estimate of effective recombination rate and average selection coefficient for HIV in chronic infection. Proc Natl Acad Sci USA. 2011;108:5661-6.

65. Fischer W, Ganusov VV, Giorgi EE, Hraber PT, Keele BF, Leitner T, Han CS, Gleasner CD, Green L, Lo C-C, et al. Transmission of single HIV-1 genomes and dynamics of early immune escape revealed by ultradeep sequencing. PLoS ONE. 2010;5:e12303.

66. Carlson JM, Du VY, Pfeifer N, Bansal A, Tan VYF, Power K, Brumme CJ, Kreimer A, DeZiel CE, Fusi N, et al. Impact of pre-adapted HIV transmission. Nat Med. 2016;22:606-13.

67. Brennan CA, Ibarrondo FJ, Sugar CA, Hausner MA, Shih R, Ng HL, Detels R, Margolick JB, Rinaldo CR, Phair J, et al. Early HLA-B*57-restricted CD8+ Tlymphocyte responses predict HIV-1 disease progression. J Virol. 2012;86:10505-16.

68. Shahid A, Olvera A, Anmole G, Kuang XT, Cotton LA, Plana M, Brander C, Brockman MA, Brumme ZL. Consequences of HLA-B*13-associated 
escape mutations on HIV-1 replication and Nef function. J Virol. 2015;89:11557-71.

69. Bar KJ, Tsao C-Y, lyer SS, Decker JM, Yang Y, Bonsignori M, Chen X, Hwang K-K, Montefiori DC, Liao H-X, et al. Early low-titer neutralizing antibodies impede HIV-1 replication and select for virus escape. PLoS Pathog. 2012;8:e1002721.

70. Hill AL, Rosenbloom DIS, Nowak MA. Evolutionary dynamics of HIV at multiple spatial and temporal scales. J Mol Med. 2012;90:543-61.

71. Waters L, Mandalia S, Randell P, Wildfire A, Gazzard B, Moyle G. The impact of HIV tropism on decreases in CD4 cell count, clinical progression, and subsequent response to a first antiretroviral therapy regimen. Clin Infect Dis. 2008;46:1617-23.

72. Wu X, Zhang Z, Schramm Chaim A, Joyce MG, Do Kwon Y, Zhou T, Sheng Z, Zhang B, O'Dell S, McKee K, et al. Maturation and diversity of the VRC01-antibody lineage over 15 years of chronic HIV-1 infection. Cell. 2015;161:470-85.

73. Liao H-X, Lynch R, Zhou T, Gao F, Alam SM, Boyd SD, Fire AZ, Roskin KM, Schramm CA, Zhang Z, et al. Co-evolution of a broadly neutralizing HIV-1 antibody and founder virus. Nature. 2013;496:469-76.

74. Palmer S, Maldarelli F, Wiegand A, Bernstein B, Hanna GJ, Brun SC, Kempf DJ, Mellors JW, Coffin JM, King MS. Low-level viremia persists for at least 7 years in patients on suppressive antiretroviral therapy. Proc Natl Acad Sci USA. 2008;105:3879-84.

75. Maldarelli F, Palmer S, King MS, Wiegand A, Polis MA, Mican J, Kovacs JA, Davey RT, Rock-Kress D, Dewar R, et al. ART suppresses plasma HIV-1 RNA to a stable set point predicted by pretherapy viremia. PLoS Pathog. 2007;3:e46.

76. Perelson AS, Essunger P, Cao Y, Vesanen M, Hurley A, Saksela K, Markowitz M, Ho DD. Decay characteristics of HIV-1-infected compartments during combination therapy. Nature. 1997;387:188-91.

77. Simonetti FR, Sobolewski MD, Fyne E, Shao W, Spindler J, Hattori J, Anderson EM, Watters SA, Hill S, Wu X, et al. Clonally expanded CD4+ T cells can produce infectious HIV-1 in vivo. Proc Natl Acad Sci USA. 2016;113:1883-8.

78. Wiegand A, Spindler J, Hong FF, Shao W, Cyktor JC, Cillo AR, Halvas EK, Coffin JM, Mellors JW, Kearney MF. Single-cell analysis of HIV-1 transcriptional activity reveals expression of proviruses in expanded clones during ART. Proc Natl Acad Sci USA. 2017;114:E3659-68.

79. Besson GJ, Lalama CM, Bosch RJ, Gandhi RT, Bedison MA, Aga E, Riddler SA, McMahon DK, Hong F, Mellors JW. HIV-1 DNA decay dynamics in blood during more than a decade of suppressive antiretroviral therapy. Clin Infect Dis. 2014;59:1312-21.

80. von Stockenstrom S, Odevall L, Lee E, Sinclair E, Bacchetti P, Killian M, Epling L, Shao W, Hoh R, Ho T, et al. Longitudinal genetic characterization reveals that cell proliferation maintains a persistent HIV type 1 DNA pool during effective HIV therapy. J Infect Dis. 2015;212:596-607.

81. Hosmane NN, Kwon KJ, Bruner KM, Capoferri AA, Beg S, Rosenbloom DI, Keele BF, Ho YC, Siliciano JD, Siliciano RF. Proliferation of latently infected CD4+ T cells carrying replication-competent HIV-1: potential role in latent reservoir dynamics. J Exp Med. 2017;214:959-72.

82. Chun TW, Carruth L, Finzi D, Shen X, DiGiuseppe JA, Taylor H, Hermankova M, Chadwick K, Margolick J, Quinn TC, et al. Quantification of latent tissue reservoirs and total body viral load in HIV-1 infection. Nature. 1997;387:183-8.

83. Chun TW, Finzi D, Margolick J, Chadwick K, Schwartz D, Siliciano RF. In vivo fate of HIV-1-infected T cells: quantitative analysis of the transition to stable latency. Nat Med. 1995;1:1284-90.

84. Henrich TJ, Hanhauser E, Marty FM, Sirignano MN, Keating S, Lee TH, Robles YP, Davis BT, Li JZ, Heisey A, et al. Antiretroviral-free HIV-1 remission and viral rebound after allogeneic stem cell transplantation: report of 2 cases. Ann Intern Med. 2014;161:319-27.

85. Luzuriaga K, Gay H, Ziemniak C, Sanborn KB, Somasundaran M, Rainwater-Lovett K, Mellors JW, Rosenbloom D, Persaud D. Viremic relapse after HIV-1 remission in a perinatally infected child. N Engl J Med. 2015;372:786-8.

86. Kearney MF, Wiegand A, Shao W, Coffin JM, Mellors JW, Lederman M, Gandhi RT, Keele BF, Li JZ. Origin of rebound plasma HIV includes cells with identical proviruses that are transcriptionally active before stopping of antiretroviral therapy. J Virol. 2015;90:1369-76.

87. Ho YC, Shan L, Hosmane NN, Wang J, Laskey SB, Rosenbloom DI, Lai J, Blankson JN, Siliciano JD, Siliciano RF. Replication-competent noninduced proviruses in the latent reservoir increase barrier to HIV-1 cure. Cell. 2013;155:540-51.

88. Pollack RA, Jones RB, Pertea M, Bruner KM, Martin AR, Thomas AS, Capoferri AA, Beg SA, Huang S-H, Karandish S, et al. Defective HIV-1 proviruses are expressed and can be recognized by cytotoxic $T$ lymphocytes, which shape the proviral landscape. Cell Host Microbe. 2017;21(494-506):e494.

89. Cory TJ, Schacker TW, Stevenson M, Fletcher CV. Overcoming pharmacologic sanctuaries. Curr Opin HIV AIDS. 2013;8:190-5.

90. Fletcher CV, Staskus K, Wietgrefe SW, Rothenberger M, Reilly C, Chipman JG, Beilman GJ, Khoruts A, Thorkelson A, Schmidt TE, et al. Persistent HIV-1 replication is associated with lower antiretroviral drug concentrations in lymphatic tissues. Proc Natl Acad Sci USA. 2014;111:2307-12.

91. Huang Y, Hoque MT, Jenabian MA, Vyboh K, Whyte SK, Sheehan NL, Brassard P, Belanger M, Chomont N, Fletcher CV, et al. Antiretroviral drug transporters and metabolic enzymes in human testicular tissue: potential contribution to HIV-1 sanctuary site. J Antimicrob Chemother. 2016;71:1954-65.

92. Chun TW, Nickle DC, Justement JS, Large D, Semerjian A, Curlin ME, O'Shea MA, Hallahan CW, Daucher M, Ward DJ, et al. HIV-infected individuals receiving effective antiviral therapy for extended periods of time continually replenish their viral reservoir. J Clin Invest. 2005;115:3250-5.

93. Boritz EA, Darko S, Swaszek L, Wolf G, Wells D, Wu X, Henry AR, Laboune $\mathrm{F}, \mathrm{Hu}$ J, Ambrozak D, et al. Multiple origins of virus persistence during natural control of HIV infection. Cell. 2016;166:1004-15.

94. Kearney MF, Wiegand A, Shao W, McManus WR, Bale MJ, Luke B, Maldarelli F, Mellors JW, Coffin JM. Ongoing HIV replication during ART reconsidered. Open Forum Infect Dis. 2017:4:ofx173-ofx173.

95. Wagner TA, MCKernan JL, Tobin NH, Tapia KA, Mullins JI, Frenkel LM. An increasing proportion of monotypic HIV-1 DNA sequences during antiretroviral treatment suggests proliferation of HIV-infected cells. J Virol. 2013:87:1770-8.

96. Dinoso JB, Kim SY, Wiegand AM, Palmer SE, Gange SJ, Cranmer L, O'Shea A, Callender M, Spivak A, Brennan T, et al. Treatment intensification does not reduce residual HIV-1 viremia in patients on highly active antiretroviral therapy. Proc Natl Acad Sci USA. 2009;106:9403-8.

97. Gandhi RT, Zheng L, Bosch RJ, Chan ES, Margolis DM, Read S, Kallungal B, Palmer S, Medvik K, Lederman MM, et al. The effect of raltegravir intensification on low-level residual viremia in HIV-infected patients on antiretroviral therapy: a randomized controlled trial. PLoS Med. 2010; 7:e1000321.

98. McMahon D, Jones J, Wiegand A, Gange SJ, Kearney M, Palmer S, McNulty S, Metcalf JA, Acosta E, Rehm C, et al. Short-course raltegravir intensification does not reduce persistent low-level viremia in patients with HIV-1 suppression during receipt of combination antiretroviral therapy. Clin Infect Dis. 2010;50:912-9.

99. Wang $X$, Mink G, Lin D, Song X, Rong L. Influence of raltegravir intensification on viral load and 2-LTR dynamics in HIV patients on suppressive antiretroviral therapy. J Theor Biol. 2017;416:16-27.

100. Joos B, Fischer M, Kuster H, Pillai SK, Wong JK, Böni J, Hirschel B, Weber R, Trkola A, Günthard HF. Swiss HIV Cohort Study TSHC: HIV rebounds from latently infected cells, rather than from continuing low-level replication. Proc Natl Acad Sci USA. 2008;105:16725-30.

101. Persaud D, Ray SC, Kajdas J, Ahonkhai A, Siberry GK, Ferguson K, Ziemniak C, Quinn TC, Casazza JP, Zeichner S, et al. Slow human immunodeficiency virus type 1 evolution in viral reservoirs in infants treated with effective antiretroviral therapy. AIDS Res Hum Retroviruses. 2007:23:381-90.

102. Van Zyl GU, Katusiime MG, Wiegand A, McManus WR, Bale MJ, Halvas EK, Luke B, Boltz VF, Spindler J, Laughton B, et al. No evidence of HIV replication in children on antiretroviral therapy. J Clin Invest. 2017;127:3827-34.

103. Vancoillie L, Hebberecht L, Dauwe K, Demecheleer E, Dinakis S, Vaneechoutte D, Mortier V, Verhofstede C. Longitudinal sequencing of HIV-1 infected patients with low-level viremia for years while on ART shows no indications for genetic evolution of the virus. Virology. 2017:510:185-93.

104. Kearney MF, Anderson EM, Coomer C, Smith L, Shao W, Johnson N, Kline C, Spindler J, Mellors JW, Coffin JM, Ambrose Z. Well-mixed plasma and tissue viral populations in RT-SHIV-infected macaques implies a lack of 
viral replication in the tissues during antiretroviral therapy. Retrovirology. 2015;12:93.

105. Bull M, Learn G, Genowati I, McKernan J, Hitti J, Lockhart D, Tapia K, Holte S, Dragavon J, Coombs R, et al. Compartmentalization of HIV-1 within the female genital tract is due to monotypic and low-diversity variants not distinct viral populations. PLOS ONE. 2009;4:e7122.

106. Nickle DC, Jensen MA, Shriner D, Brodie SJ, Frenkel LM, Mittler JE, Mullins J. Evolutionary indicators of human immunodeficiency virus type 1 reservoirs and compartments. J Virol. 2003;77:5540-6.

107. van Marle G, Gill MJ, Kolodka D, McManus L, Grant T, Church DL. Compartmentalization of the gut viral reservoir in HIV-1 infected patients. Retrovirology. 2007:4:87.

108. YukI SA, Gianella S, Sinclair E, Epling L, Li Q, Duan L, Choi AL, Girling V, Ho T, Li P, et al. Differences in HIV burden and immune activation within the gut of HIV-positive patients receiving suppressive antiretroviral therapy. J Infect Dis. 2010;202:1553-61.

109. Rueda CM, Velilla PA, Chougnet CA, Montoya CJ, Rugeles MT. HIVinduced T-cell activation/exhaustion in rectal mucosa is controlled only partially by antiretroviral treatment. PLoS ONE. 2012;7:e30307.

110. Imamichi H, Degray G, Dewar RL, Mannon P, Yao M, Chairez C, Sereti I, Kovacs JA. Lack of compartmentalization of HIV-1 quasispecies between the gut and peripheral blood compartments. J Infect Dis. 2011;204:309-14.

111. Stefic K, Chaillon A, Bouvin-Pley M, Moreau A, Braibant M, Bastides F, Gras G, Bernard L, Barin F. Probing the compartmentalization of HIV-1 in the central nervous system through its neutralization properties. PLoS ONE. 2017;12:e0181680

112. Evering TH, Kamau E, St Bernard L, Farmer CB, Kong XP, Markowitz M. Single genome analysis reveals genetic characteristics of Neuroadaptation across HIV-1 envelope. Retrovirology. 2014;11:65.

113. Ritola K, Pilcher CD, Fiscus SA, Hoffman NG, Nelson JA, Kitrinos KM Hicks CB, Eron JJ Jr, Swanstrom R. Multiple V1/N2 env variants are frequently present during primary infection with human immunodeficiency virus type 1. J Virol. 2004;78:11208-18.

114. Chomont N, Hocini H, Gresenguet G, Brochier C, Bouhlal H, Andreoletti L, Becquart P, Charpentier C, de Dieu Longo J, Si-Mohamed A, et al. Early archives of genetically-restricted proviral DNA in the female genital tract after heterosexual transmission of HIV-1. AIDS. 2007:21:153-62.

115. Chaudhary S, Noel RJ, Rodriguez N, Collado S, Munoz J, Kumar A, Yamamura Y. Correlation between CD4T cell counts and virus compartmentalization in genital and systemic compartments of HIV-infected females. Virology. 2011;417:320-6.

116. Blasi M, Carpenter JH, Balakumaran B, Cara A, Gao F, Klotman ME. Identification of HIV-1 genitourinary tract compartmentalization by analyzing the env gene sequences in urine. AIDS. 2015;29:1651-7.

117. Bull ME, Learn GH, McElhone S, Hitti J, Lockhart D, Holte S, Dragavon J, Coombs RW, Mullins JI, Frenkel LM. Monotypic human immunodeficiency virus type 1 genotypes across the uterine cervix and in blood suggest proliferation of cells with provirus. J Virol. 2009;83:6020-8.

118. Bull ME, Heath LM, McKernan-Mullin JL, Kraft KM, Acevedo L, Hitti JE, Cohn SE, Tapia KA, Holte SE, Dragavon JA, et al. Human immunodeficiency viruses appear compartmentalized to the female genital tract in cross-sectional analyses but genital lineages do not persist over time. J Infect Dis. 2013;207:1206-15.

119. Chaillon A, Smith DM, Vanpouille C, Lisco A, Jordan P, Caballero G, Vargas M, Gianella S, Mehta SR. HIV trafficking between blood and semen during early untreated HIV infection. J Acquir Immune Defic Syndr. 2017;74:95-102

120. Delchambre M, Gheysen D, Thines D, Thiriart C, Jacobs E, Verdin E, Horth M, Burny A, Bex F. The GAG precursor of simian immunodeficiency virus assembles into virus-like particles. EMBO J. 1989;8:2653-60.

121. Eriksson S, Graf EH, Dahl V, Strain MC, YukI SA, Lysenko ES, Bosch RJ, Lai J, Chioma S, Emad F, et al. Comparative analysis of measures of viral reservoirs in HIV-1 eradication studies. PLoS Pathog. 2013:9:e1003174.

122. Wainberg MA, Rooke R, Tremblay M, Li X, Parniak MA, Gao Q, Yao XJ, Tsoukas C, Montaner J, Fanning M, Ruedy J. Clinical significance and characterization of AZT-resistant strains of HIV-1. Can J Infect Dis. 1991;2:5-11.

123. Collier AC, Coombs RW, Schoenfeld DA, Bassett RL, Timpone J, Baruch A, Jones M, Facey K, Whitacre C, McAuliffe VJ, et al. Treatment of human immunodeficiency virus infection with saquinavir, zidovudine, and zalcitabine. N Engl J Med. 1996;334:1011-8.
124. Montaner JS, Hogg R, Raboud J, Harrigan R, O'Shaughnessy M. Antiretroviral treatment in 1998. The Lancet. 1998;352:1919-22.

125. Montaner JS, Reiss P, Cooper D, Vella S, Harris M, Conway B, Wainberg MA, Smith D, Robinson P, Hall D, et al. A randomized, double-blind trial comparing combinations of nevirapine, didanosine, and zidovudine for HIV-infected patients: the INCAS Trial. Italy, The Netherlands, Canada and Australia Study. JAMA. 1998;279:930-7.

126. Altmann A, Beerenwinkel N, Sing T, Savenkov I, Doumer M, Kaiser R, Rhee S-Y, Fessel WJ, Shafer RW, Lengauer T. Improved prediction of response to antiretroviral combination therapy using the genetic barrier to drug resistance. Antivir Ther. 2007;12:169-78.

127. Brenner BG, Wainberg MA. Clinical benefit of dolutegravir in HIV-1 management related to the high genetic barrier to drug resistance. Virus Res. 2017;239:1-9.

128. Gantner P, Cuzin L, Allavena C, Cabie A, Pugliese P, Valantin M-A, Bani-Sadr F, Joly V, Ferry T, Poizot-Martin I, et al. Efficacy and safety of dolutegravir and rilpivirine dual therapy as a simplification strategy: a cohort study. HIV Medicine. 2017;18:704-8.

129. Maggiolo F, Gulminetti R, Pagnucco L, Digaetano M, Benatti S, Valenti D, Callegaro A, Ripamonti D, Mussini C. Lamivudine/dolutegravir dual therapy in HIV-infected, virologically suppressed patients. BMC Infect Dis. 2017:17:215.

130. Lepik KJ, Harrigan PR, Yip B, Wang L, Robbins MA, Zhang WW, Toy J, Akagi L, Lima VD, Guillemi S, et al. Emergent drug resistance with integrase strand transfer inhibitor-based regimens. AIDS. 2017;31:1425-34.

131. Naeger LK, Harrington P, Komatsu T, Deming D. Effect of dolutegravir functional monotherapy on HIV-1 virological response in integrase strand transfer inhibitor resistant patients. Antivir Ther. 2016;21:481-8.

132. Oldenbuettel C, Wolf E, Ritter A, Noe S, Heldwein S, Pascucci R, Wiese C, Von Krosigk A, Jaegel-Guedes E, Jaeger H, et al. Dolutegravir monotherapy as treatment de-escalation in HIV-infected adults with virological control: DoluMono cohort results. Antivir Ther. 2016;22:169-72.

133. Rabi SA, Laird GM, Durand CM, Laskey S, Shan L, Bailey JR, Chioma S, Moore RD, Siliciano RF. Multi-step inhibition explains HIV-1 protease inhibitor pharmacodynamics and resistance. J Clin Invest. 2013;123:3848-60.

134. Sampah MES, Shen L, Jilek BL, Siliciano RF. Dose-response curve slope is a missing dimension in the analysis of HIV-1 drug resistance. Proc Natl Acad Sci. 2011;108:7613-8.

135. Jourdain G, Ngo-Giang-Huong N, Le Coeur S, Bowonwatanuwong C, Kantipong P, Leechanachai P, Ariyadej S, Leenasirimakul P, Hammer $\mathrm{S}$, Lallemant M. Intrapartum exposure to nevirapine and subsequent maternal responses to nevirapine-based antiretroviral therapy. N Engl J Med. 2004:351:229-40.

136. Boltz VF, Bao Y, Lockman S, Halvas EK, Kearney MF, McIntyre JA, Schooley RT, Hughes MD, Coffin JM, Mellors JW, Team OA. Low-frequency nevirapine (NVP)-resistant HIV-1 variants are not associated with failure of antiretroviral therapy in women without prior exposure to single-dose NVP. J Infect Dis. 2014;209:703-10

137. Li JZ, Paredes R, Ribaudo HJ, Svarovskaia ES, Kozal MJ, Hullsiek KH, Miller MD, Bangsberg DR, Kuritzkes DR. Relationship between minority nonnucleoside reverse transcriptase inhibitor resistance mutations, adherence, and the risk of virologic failure. AIDS (London, England). 2012;26:185-92.

138. Goodman DD, Zhou Y, Margot NA, McColl DJ, Zhong L, Borroto-Esoda K, Miller MD, Svarovskaia ES. Low level of the K103N HIV-1 above a threshold is associated with virological failure in treatment-naive individuals undergoing efavirenz-containing therapy. AIDS. 2011;25:325-33.

139. Parienti JJ, Das-Douglas M, Massari V, Guzman D, Deeks SG, Verdon R, Bangsberg DR. Not all missed doses are the same: sustained NNRTI treatment interruptions predict HIV rebound at low-to-moderate adherence levels. PLoS ONE. 2008:3:e2783.

140. Hosseinipour MC, Gupta RK, Van Zyl G, Eron JJ, Nachega JB. Emergence of HIV drug resistance during first- and second-line antiretroviral therapy in resource-limited settings. J Infect Dis. 2013;207:S49-56.

141. Coffin JM. HIV population dynamics in vivo: implications for genetic variation, pathogenesis, and therapy. Science. 1995;267:483-9.

142. Mansky LM, Temin HM. Lower in vivo mutation rate of human immunodeficiency virus type 1 than that predicted from the fidelity of purified reverse transcriptase. J Virol. 1995;69:5087-94. 